\title{
NLWKN \\ Risk assessment for North Sea coastal lowlands Influence of different coastal defence systems on flooding in case of failure Holger B (um ${ }^{11}$, Frank Thorenz'), Hans-J örg Lambrecht'
}

INTRODUCTION

The German Federal State Lower Saxony borders on its northern side the southern North Sea. The coastal lowlands of Lower Saxony represent an important economical, agricultural, cultural and ecological area. About $6,600 \mathrm{~km}^{2}$ with 1.2 million inhabitants are flood prone by storm surges. The main coastal defence elements on the mainland coast are main dikes and storm surge barriers. In case of main dikes, on significant stretches of the coastline additional protection elements such as dike forelands and secondary dike lines are present (Blum et al., 2011).

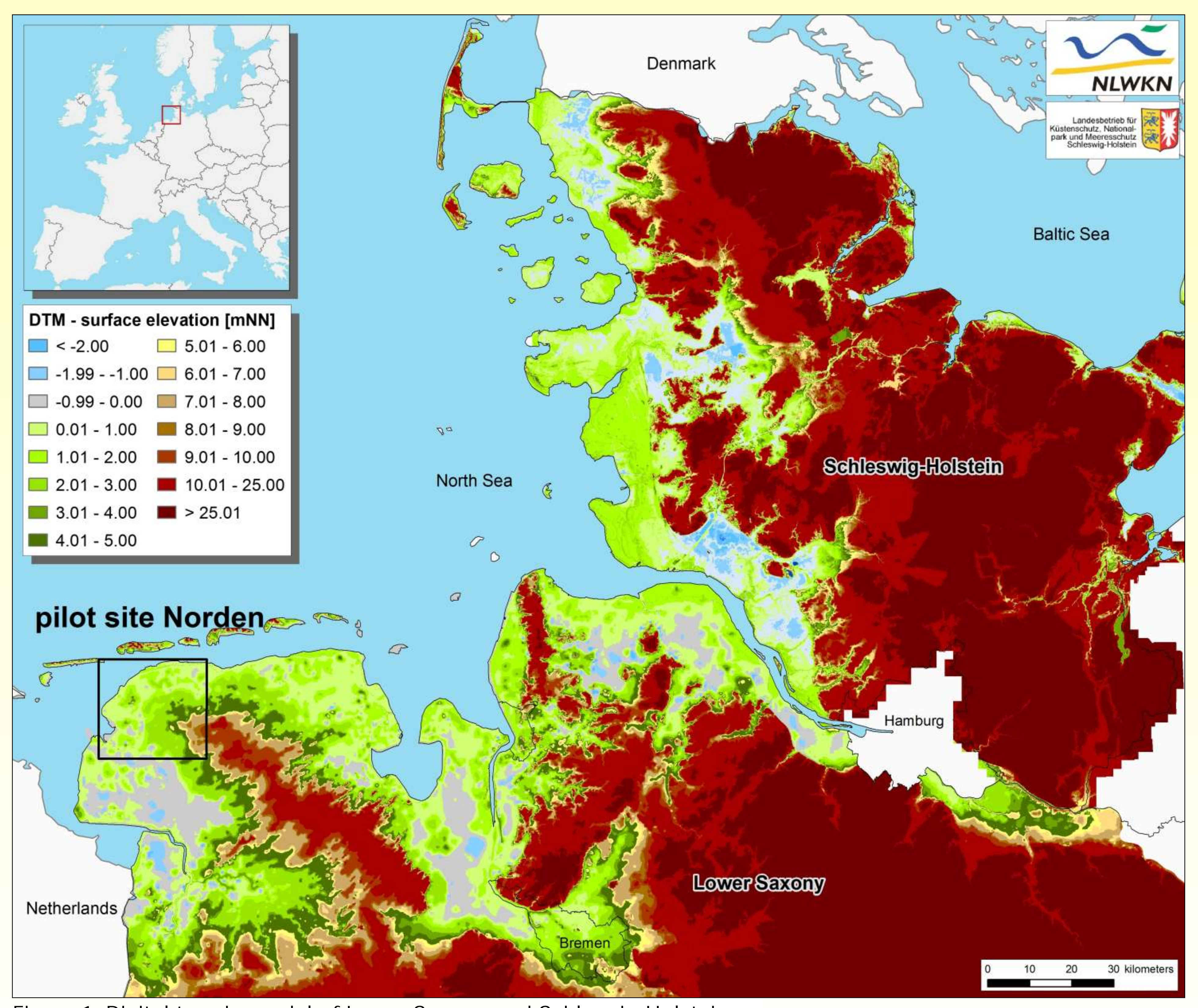

Figure 1: Digital terrain model of Lower Saxony and Schleswig-Holstein

Aspects of flooding due to failure of coastal defences and the consequences are investigated by the Lower Saxony Water Management, Coastal Defence and Nature Conservation Agency (NLWKN) within two research projects SAFECOAST (Safecoast, 2008) and HoRisK (Flood Risk Management for Coastal Areas) in order to facilitate technical aspects of the EU Flood Risk Management Directive's implementation.

\section{OBJ ECTIVES AND METHODS}

Within subproject HoRisK-C 'Consequences of Flooding at the North Sea Coast' led by NLWKN, hydrodynamic flooding simulations are performed for selected boundary conditions and failure scenarios of the coastal defence system. Aims of the investigations are damage and risk assessments as well as methods to reduce damages and risks. In order to estimate the damages the Source-Pathway-Receptor approach is adopted. The subproject HoRisk-C focuses mainly on the latter aspects. A hydrodynamic model and a geographical information system (GIS) are used to determine flood propagation, water depth and resulting damages.

The results of the investigations conducted in SAFECOAST delivered significant influences of topographical elements such as drainage systems, positive break lines and small variations of elevation on the simulated inundation (Burg et al., 2008; Thorenz et al., 2008).

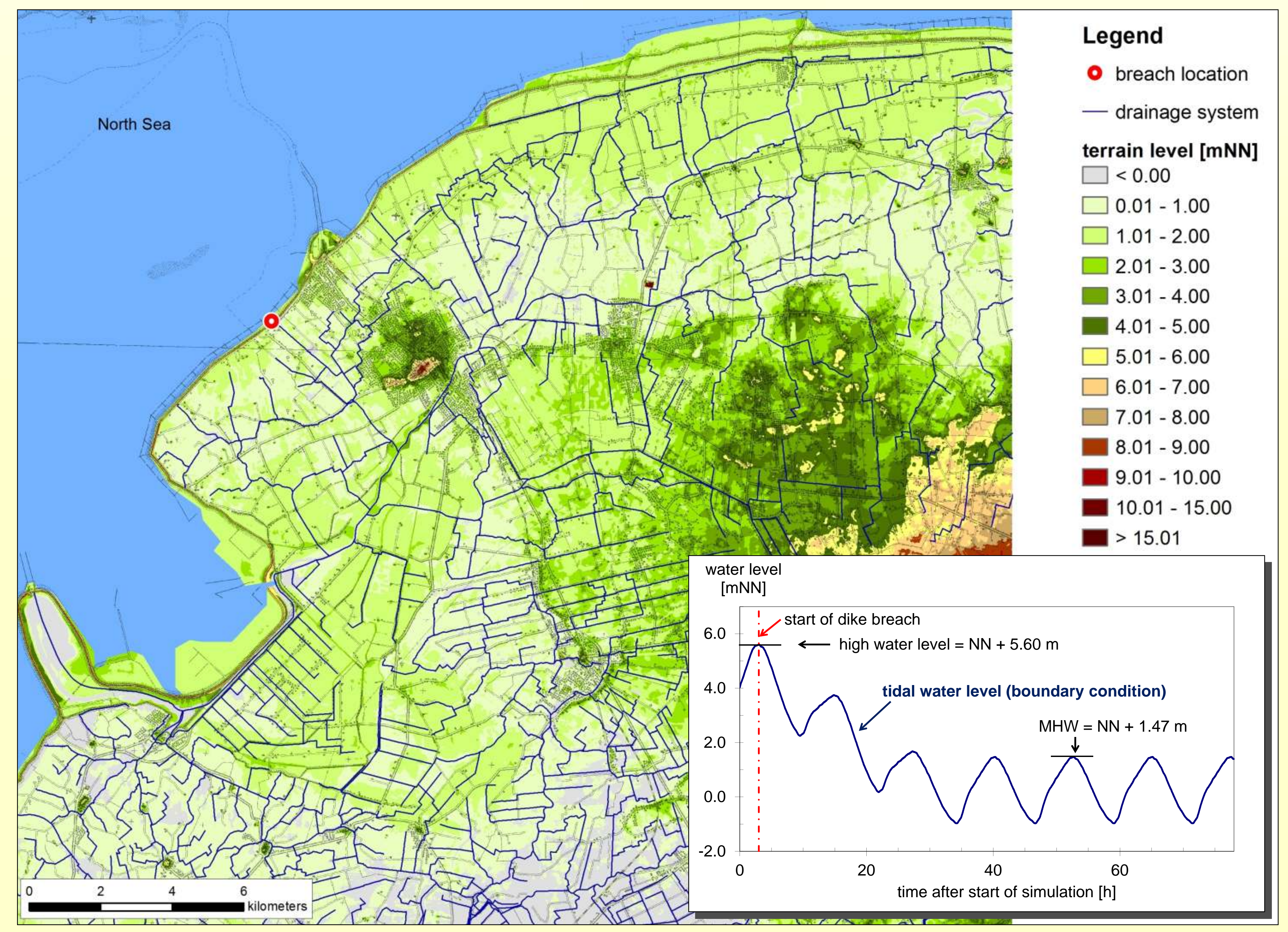

Figure 2: Hydraulic boundary condition and digital terrain model of pilot site 'Norden'
Taking these findings into account, main objectives of HoRisK-C are investigations regarding the consequences of failure for coastal lowlands protected by different coastal defence systems. Therein included are the influence of specific defence elements and topography on flood propagation and extension. In a further phase of the project the findings will be integrated in options to reduce exposure of receptors and risks in flood prone coastal areas.

FIRST RESULTS

For the pilot site 'Norden' hydrodynamic simulations of a dike failure scenario using a $50 \times 50 \mathrm{~m}$ terrain model, a uniform $150 \mathrm{~m}$ breach width and a drainage system yield flood extension and maximum water depth. Calculations are conducted for the existing coastal defence system consisting only of a main dike as well as for two modified systems based on this existing. One modified system represents a theoretical foreland (fig. 3c) whereas the other is a combination of the theoretical foreland and a summer dike, i.e. a small dike with crest height of NN $+3.0 \mathrm{~m}$ in front of the main dike line (fig. $3 \mathrm{~d}$ ). Simulation confirmed the findings of Burg et al. (2008) concerning numerical implementation of drainage systems (fig. 3a) and breach scenarios (fig. 3b).

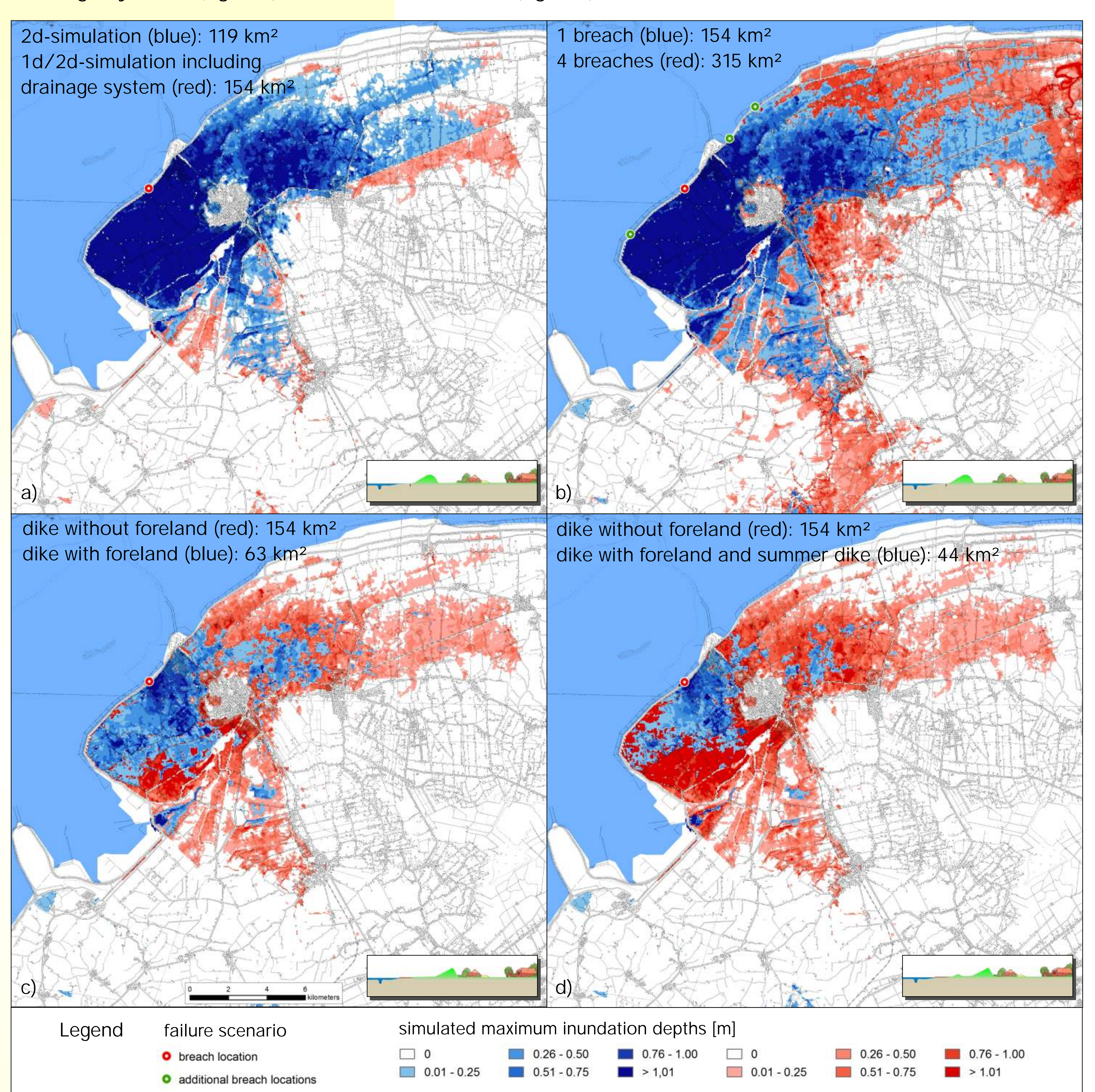

Figure 3: Comparison of flooded area and max. water depth for dike failure scenario simulated by taking into account different a) simulation approaches, b) number of breaches and c) d) types of coastal defence systems

CONCLUSIONS

The hydrodynamic simulations show, that in comparison of a coastal defence system 'dike without foreland' a system 'with foreland' or 'with foreland and summer dike' will reduce the inflow volume as well as the flooded area, significantly.

The foreland in front of dikes is subject of the Lower Saxony Dike Law and the Lower Saxony Master Plan Coastal Defence. There its functionality to protect the dike by reduction of the loads, e.g. currents, is addressed. The effect of reducing the inflow volume through a breach in case of a failure of the coastal defence system was shown for selected synthetic and real cases. As a consequence a foreland of sufficient height and width can reduce the consequences for the hinterland and should be taken into account for flooding calculations.

\section{ACKNOWLEDGEMENTS}

HoRisK is funded as a research project of the German Coastal Engineering Research Council (KFKI) by Federal Ministry of Research (BMBF) under project number 03KIS080. SAFECOAST was funded by the EU INTERREG Illb North Sea Region programme.

REFERENCES

Blum, Thorenz, Lambrecht (2011): The risk assessment for North Sea coastal lowlands. Proc. 5th SCACR conference, Aachen, Germany.

Burg, Thorenz, Blum (2008): Coastal Flood Inundation Modelling for North Sea Lowlands. Proc Floodsite conference, Oxford, UK.

Safecoast (2008): Coastal Flood Risk and Trends for the Future in the North Sea Region. Synthesis report. Safecoast project team, pp. 136. The Hague, The Netherlands.

Thorenz, Burg (2008): Risk Assessment for Coastal Lowlands in Lower Saxony. Proc. Fourth Chinese-German J oint Symposium on Coastal and Ocean Engineering. Darmstadt, Germany.

CONTACT

Lower Saxony Water Management, Coastal Defence and Nature Conservation Agency (NLWKN) Betriebsstelle Norden-Norderney, J ahnstrasse 1, D-26056 Norden, Germany ${ }^{11}$ holger.blum@ nlwkn-nor.niedersachsen.de

frank.thorenz@ nlwkn-nor.niedersachsen.de

hans-joerg.lambrecht@ nlwkn-nor.niedersachsen.de

Funded under reference 03 KIS080 by:

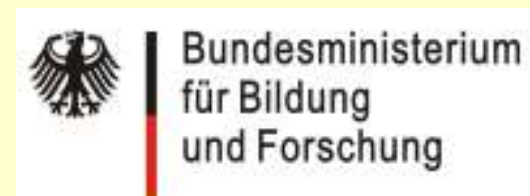

PU 